\title{
Paleopathology in South American Mummies: A Review and New Findings
}

\author{
Enrique Gerszten Marvin J. Allison Brianna Maguire \\ Department of Pathology, Medical College of Virginia Campus, Virginia Commonwealth University, \\ Richmond, Va., USA
}

\section{Key Words}

Cardiovascular diseases • Infections • Mummies •

Neoplasms • Traumas

\begin{abstract}
This article is a review of research and additional unpublished diseases that have been discovered and documented in naturally mummified remains recovered from South America. A new impetus in paleopathological studies was the work and discovery of a solution for rehydration of mummified tissues by Sir Marc Armand Ruffer in 1913. This solution allows the paleopathologist, after performing the autopsy, to process the tissues in a manner similar to current practices in pathology. In our studies, the most common diseases were infectious in nature, similar to the diseases that are most prominent today in the same regions.
\end{abstract}

Copyright $\odot 2012$ S. Karger AG, Basel

\section{Introduction}

This article is a review of almost 40 years of research on mummified human and animal remains that were excavated mainly from southern Peru and northern Chile. This is not only a review of our published findings, but also includes new, unpublished research findings on in- fectious diseases that afflicted the peoples of ancient times. The study of diseases in antiquity, also known as the field of 'paleopathology', began with the pioneering work of Sir Marc Armand Ruffer (fig. 1) with Egyptian mummies in the early 20th century [1]. One of the most significant contributions by Sir Ruffer was the discovery of the solution that bears his name that allows mummified or dried tissues to be rehydrated. The sample of tissues can later be embedded, cut, and stained in a similar fashion to the way in which samples from biopsies and autopsies of contemporary people are examined nowadays. It is well known in paleopathological circles that Sir Ruffer coined the first definition of paleopathology in 1913: 'The science of the diseases which can be demonstrated in human and animal remains of ancient times.' Rudolf Virchow, who is best known as the founder of the field of pathology, also performed investigations on Egyptian mummies as well as ancient human skeletal remains from Russia.

\section{Geography}

The mummified remains that were studied in our investigations were mainly excavated from two regions: the Ica Valley in southern Peru and the Azapa Valley in northern Chile. In ancient times, before the Spaniards con-

\section{KARGER}

Fax +4161306 1234

E-Mail karger@karger.ch

www.karger.com
(C) 2012 S. Karger AG, Basel

1015-2008/12/0795-0247\$38.00/0

Accessible online at:

www.karger.com/pat
Dr. Enrique Gerszten, MD

Department of Pathology

Medical College of Virginia, PO Box 980662

Richmond, VA 23298-0662 (USA)

Tel. +1 804827 1080, E-Mail egerszten2@ mcvh-vcu.edu 


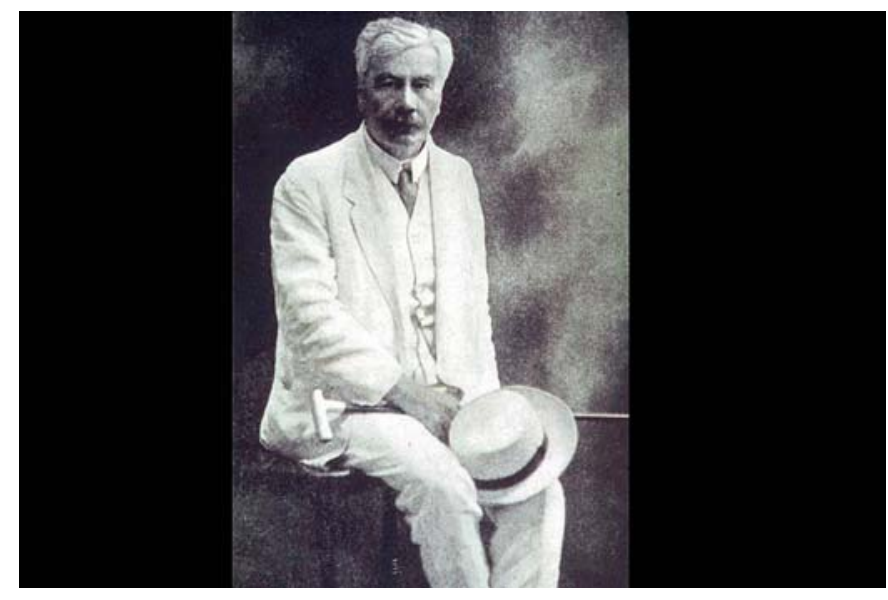

Fig. 1. Sir Marc Armand Ruffer (1859-1917).

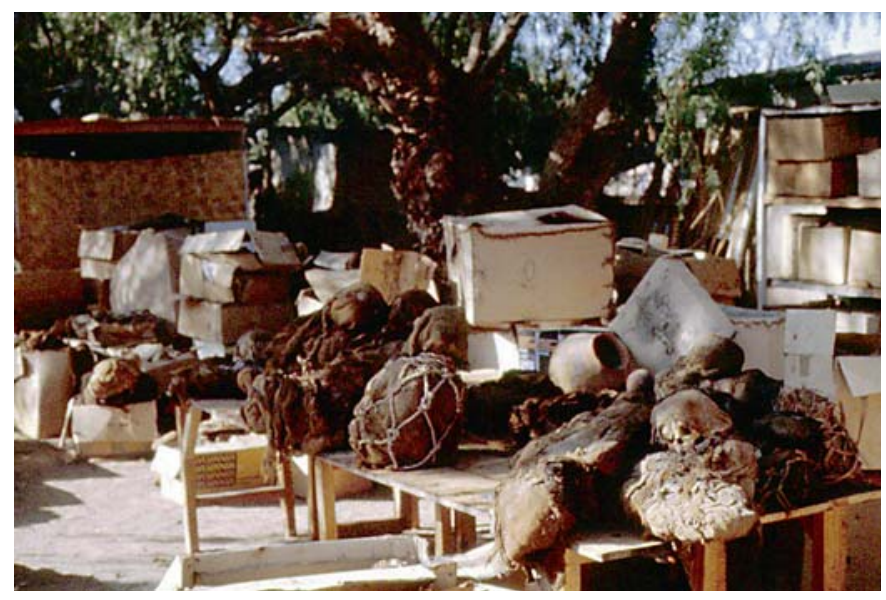

Fig. 3. Mummies and artifacts recovered from an excavation.

quered this region in the 16th century, the Incan Empire ruled this entire area. Thislarge geographical area spanned from the west of the Andes, from southern Ecuador to northern Chile and crossed the Andes to some areas of western Bolivia and northern Argentina. This unique geographical region of the globe allowed many civilizations to flourish despite the barren topography due to the eternal snow of the cordillera of the Andes. The snow melts during the day, forming small lakes and rivers that run west into the Pacific Ocean (fig. 2). This eternal source of water allowed the natives to have a successful agricultural lifestyle on both sides of the Andes. During the last 20 years, we concentrated our research efforts on the Azapa Valley, which has been inhabited by humans for almost

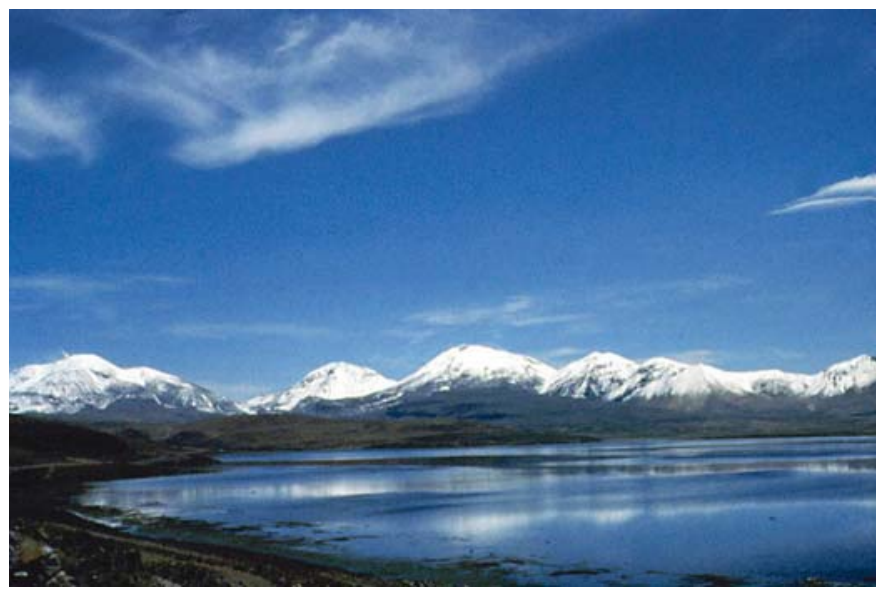

Fig. 2. Cordillera of the Andes in South America.

8,000 years. Eight distinct cultures developed in this limited area. Using carbon-14 analysis and the extensive archaeological material excavated, anthropologists have been able to easily identify each unique cultural group. This opportunity allowed us to study the possibility of cyclic changes in diseases over an extended period of time in a single, relatively small geographical area.

\section{Burials and Autopsy}

All of the civilizations of the Azapa Valley of northern Chile buried their dead in cemeteries located near to their living quarters. The burials contained clothing, food, and artifacts that had been used by the deceased in daily life. The native peoples believed that the dead would use these items in the afterlife. Local archaeologists, who are very skilled in locating the cemeteries, performed all of our excavations.

The most typical burial was for the body to be wrapped in cloth and bound with a cord (fig. 3). The bodies were always found in the flexed, or 'fetal' burial position, with the extremities folded close to the thorax and abdomen. After the mummy had been excavated and transported to the laboratory, the anthropologist identified the cultural period during which the mummified person had lived. The next step was for the paleopathologist to perform the autopsy. Prior to beginning the autopsy, it was usually necessary to take X-rays of the body. The purpose of the autopsy was to identify any chronic diseases from which the person had suffered and the possible cause of death. 


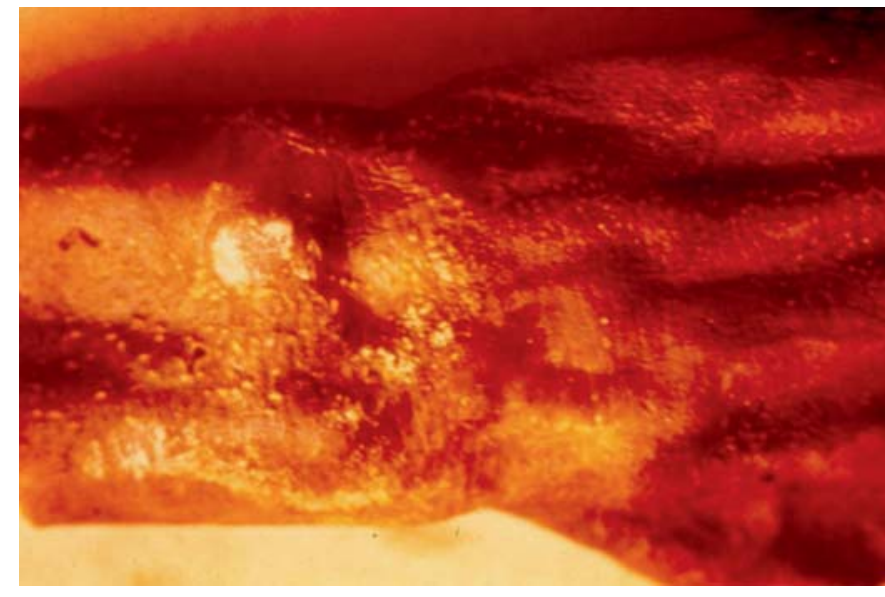

Fig. 4. Multiple lesions on a mummified hand after it was rehydrated in Ruffer's solution.

The techniques used to perform the autopsy were very similar to those in modern practices. The diseases found were divided in the same manner as today: infectious, neoplastic, genetic, hemodynamic, immunological, environmental, and nutritional. In our studies, we attempted to focus on the following systems or organs: skeletal, cardiovascular, pulmonary, gastrointestinal tract, urinary, skin, central nervous, liver, and breast.

\section{Infectious Diseases}

Infectious diseases in humans are most commonly due to bacteria or viruses. However, other types of infections, such as mycobacterial and fungal infections, are sporadically seen. In antiquity as well as in the present, the most common infections in humans occur in the lungs. The vast majority of what appeared to be the primary cause of death in our studies of the mummies was pneumonia. Nowadays, in the same geographical areas, pneumonia continues to be the most common cause of death. In modern industrial countries, cardiovascular diseases are the main causes of death. On the other hand, in developing countries, the main and immediate cause of death is still infectious.

The etiology of infectious diseases was diagnosed in mummified tissues using the normal stain, hematoxylin and eosin (HE), or special stains. The organisms responsible for the infection can still be stained and the bacteria can be determined as Gram-positive or Gram-negative. However, the inflammatory reaction can seldom be seen because the white cells have undergone autolytic changes.
Contrary to white blood cells, red blood cells are usually well preserved and easily identified. In our studies, the infections in the lung and some in the heart showed that the more common etiological agent was a Gram-positive organism.

\section{Bacterial Infections}

Carrion's Disease

Carrion's disease is caused by the bacterium Bartonella bacilliformis. This bacterium is more commonly spread to humans through a bite from one of several different species of sand flies [2]. Due to the presence of a vector, the disease tends to be limited to the areas where the vector is found, generally on either side of the Andes. The infection occurs in two stages; the first stage is known as Oroya fever, which is accompanied by severe and sometimes fatal anemia. Anyone who survives this is at risk to develop the second stage. The second stage presents with wart-like lesions on the skin, varying in size.

One of our pre-Columbian mummies [3] was noted to have lesions and multiple nodules all over the body (fig. 4). After performing the autopsy, skin sections from the lesions were studied with HE, Gram, and Giemsa stains to try to identify the organisms. In addition, electron microscopy was performed. The electron microscope showed a long undulating flagellum (fig. 5). The organism $B$. bacilliformis is difficult to stain with Gram stain but easily stained with Giemsa. It is commonly found inside red blood cells where it is responsible for the production of anemia. The organism is also considered to be monoflagellated or may have 1-10 flagella in a tuft at one pole of the body, many times the length of the body. The size of the body found under the electron microscope was compatible with $B$. bacilliformis.

\section{Mycobacteria tuberculosis}

In 1973, we described the first case of tuberculosis proven by staining the organisms in several different mummified soft tissues. The case involved a child from the Nazca culture of southern Peru, a culture dated to approximately $700 \mathrm{AD}$ [4]. Terminal hematogenic spread of tuberculosis was also detected involving the lung, liver, and kidneys. X-ray studies revealed Pott's disease of the lumbar spine involving the first, second, and third lumbar vertebrae. There was an area of density on radiographic examination within the soft tissue of the psoas muscle; subsequently, an abscess was found in this area. Subsequent studies [5] also confirmed that tuberculosis was a pre-Columbian disease prevalent in that area using a technique for DNA analysis [6], among other methods. 
5

Fig. 5. Picture of the electron microscope showing B. bacilliformis with a long, undulating flagellum.

Fig. 6. Paracoccidioidomycosis showing multiple buddings creating a 'ship's wheel' image.

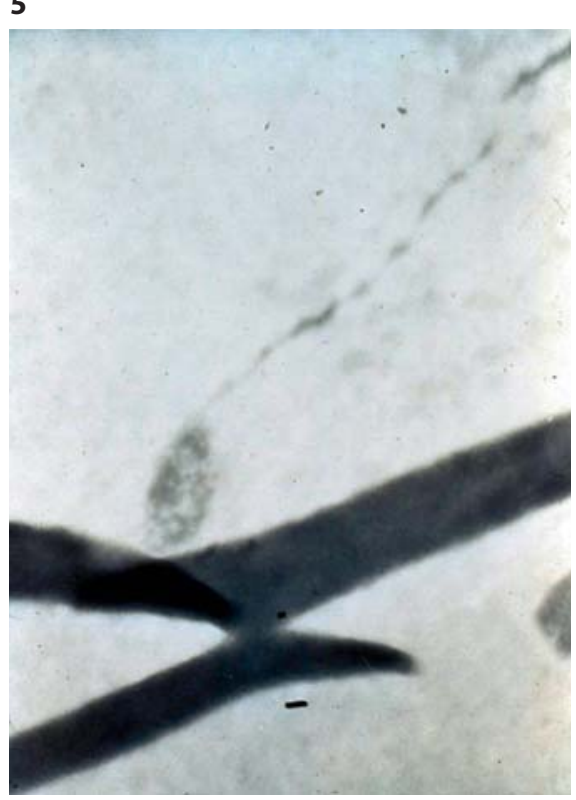

\section{6}

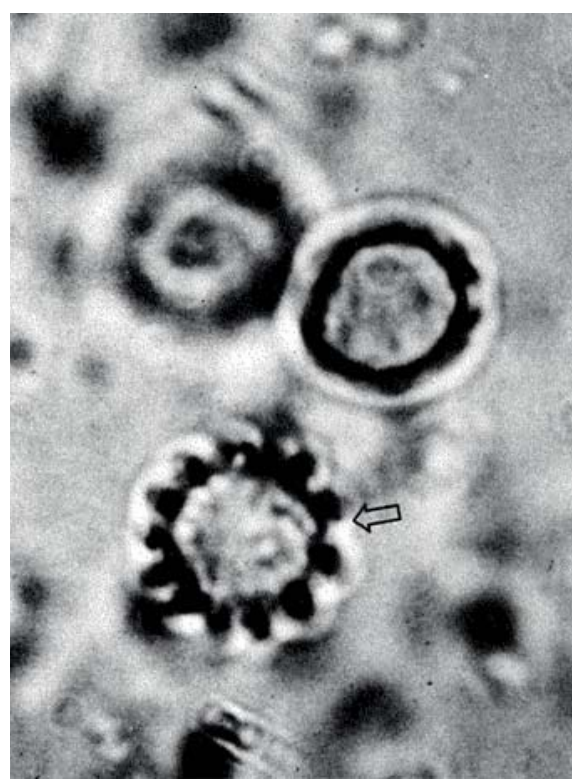

\section{Fungal Infections}

To date, three different mycotic infections have been found: several cases of candidiasis, one case of paracoccidioidomycosis, and one of coccidioidomycosis.

\section{Paracoccidioidomycosis}

We reported a case of South American blastomycosis (paracoccidioidomycosis), or Lutz-Splendore-Almeida disease [7]. It is a chronic, deep mycotic disease found almost exclusively in South America. The disease has a low incidence among adult rural populations in tropical or subtropical climates.

The mummy of a person who died during the third century in northern Chile represents the earliest reported case of paracoccidioidomycosis in South America. This was a mummy of a woman approximately 55 years of age. Upon autopsy, it was discovered that the woman had several scars of parturition, indicating multiple births. In addition, the tracheobronchial and mediastinal lymph nodes involved were mostly located on the right side, upon examination and removal of the lungs. The severity of her case can be illustrated by the deep involvement of her right-side lymph nodes. Her heart was grossly normal and her lungs were removed for further study. There was bloody fluid remaining in her lungs presenting as blackish granules. Much like the diagnosis of this infection in contemporary persons, it was initially a difficult case due to the similarities of the lungs' condition to someone afflicted with tuberculosis [8]. However, upon microscopic examination, there was a typical feature found: the yeastlike organisms were 6-12 $\mu \mathrm{m}$ in size and had multiple buddings creating the shape of a 'ship's wheel,' (fig. 6). This feature is indicative of a fungal infection with paracoccidioidomycosis.

\section{Coccidioidomycosis}

The following is an unpublished report of a coccidioidomycosis infection in a pre-Columbian 25-year-old female. She was a Tiawanaku mummy that was excavated from a cemetery near the port of Ilo, Peru. The woman had died about 1,200 years ago. The radiographs showed calcifications of the tracheobronchial lymph nodes. An open pubic symphysis and sacro-iliac articulations were indicative of a recent delivery. She had extensive nodular disease of the right breast with a few nodules (fig. 7) also found in the left breast. At autopsy, she was found to have died from a massive uterine hemorrhage indicative of death during childbirth. Tissue samples were taken of the lungs and breast nodules. Histological sections (fig. 8) were stained with HE, Masson's trichrome and Giemsa. Unstained slides were examined with polarized light and stained slides were examined with regular light microscopy. The slides clearly showed a fungal infection of Coccidiodes immitis with the accompanying endospores.

We had the opportunity to personally review the first case published by Dr. Alejandro Posada in 1892 [9]. The Museum of the Department of Pathology, University of 


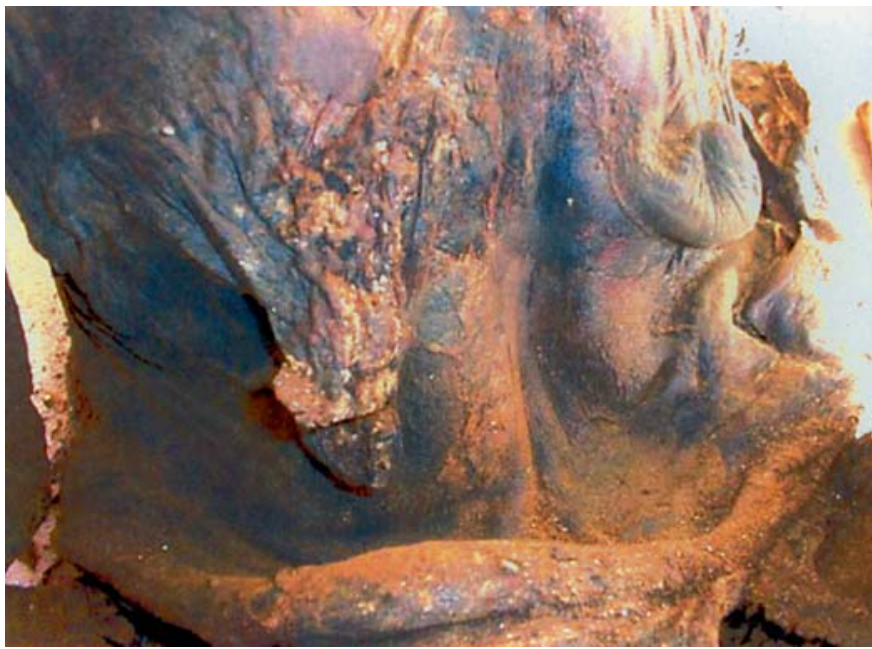

Fig. 7. Multiple subcutaneous nodules are seen on the breasts.

Buenos Aires, Argentina, still contains a foot, wrist, and hand (fig. 9) taken from the original autopsy. With the director of the museum, Dr. Jose Napoli, we took another biopsy from the foot and examined it to confirm the original diagnosis.

The case was an Argentine soldier who in his lifetime served a year in the Chaco War near the Paraguay border in 1888. He first noted what he assumed to be an insect bite on his right cheek. It grew larger, ulcerated and was soon accompanied by others that eventually formed one large mass with pus. Subsequently, skin lesions also erupted on his nose, thorax, abdomen, and limbs. He was under observation in a hospital in Buenos Aires where he was treated with iodine salts and mercury for 20 days with no improvement. A 22-year-old intern, Dr. Alejandro Posada, became interested in the case and took a number of skin biopsies. He reported the disease as 'mycosis fungoides' due to a new fungus species, which he placed in the Psorospermia. Our retaken biopsies showed giant multinucleated cells (fig. 10) containing the fungus in different grades of evolution, confirming the diagnosis of the first case of coccidioidomycosis. Dr. Jose Napoli performed subsequent studies using genetic characterization of the fungus [10] to classify the species.

\section{Viral Infections}

Herpes simplex, Epstein-Barr and cytomegalovirus are all herpes viruses that establish a permanent residence in the human host until death. Hepatitis B and C

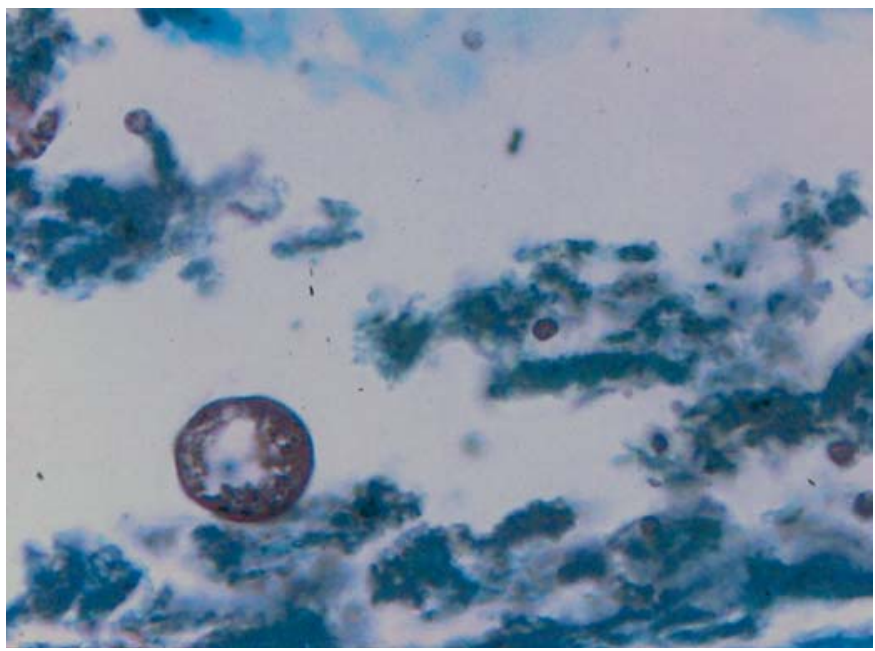

Fig. 8. Section of the right breast, showing one intact spherule containing numerous endospores of $C$. immitis.

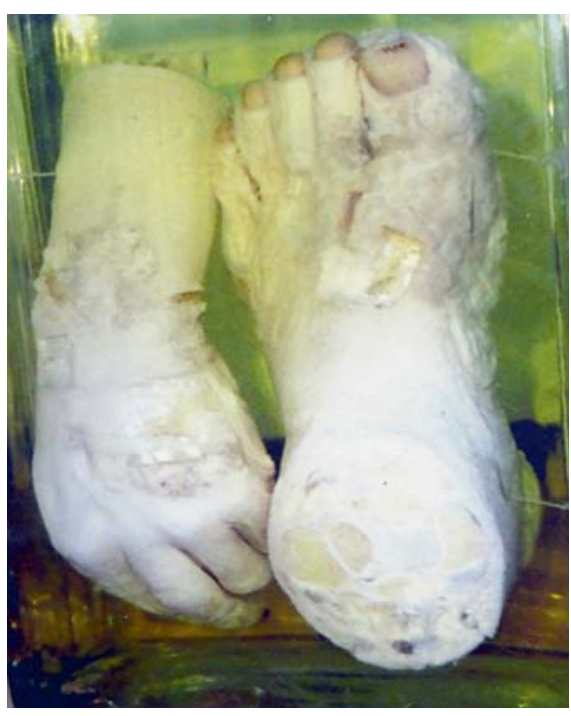

Fig. 9. A hand with wrist and a foot of the first case of coccidioidomycosis, described by Dr. A. Posada, showing skin lesions.

are also long-term residents of humans. Antibody tests for the detection of viral antigens as well as some nucleic acid probes used in in situ hybridization were identified in the liver, spleen, and kidney sections from Andean South American mummies [11]. Antigens for hepatitis B virus were found in $19 \%$ and for hepatitis $C$ virus in $34 \%$ of the mummies. Herpes type 1 was noted in $50 \%$, herpes 
Fig. 10. Histological section from the foot with HE stain showing a giant cell containing several spherules of $C$. immitis.

Fig. 11. Skull showing extensive periostitis.
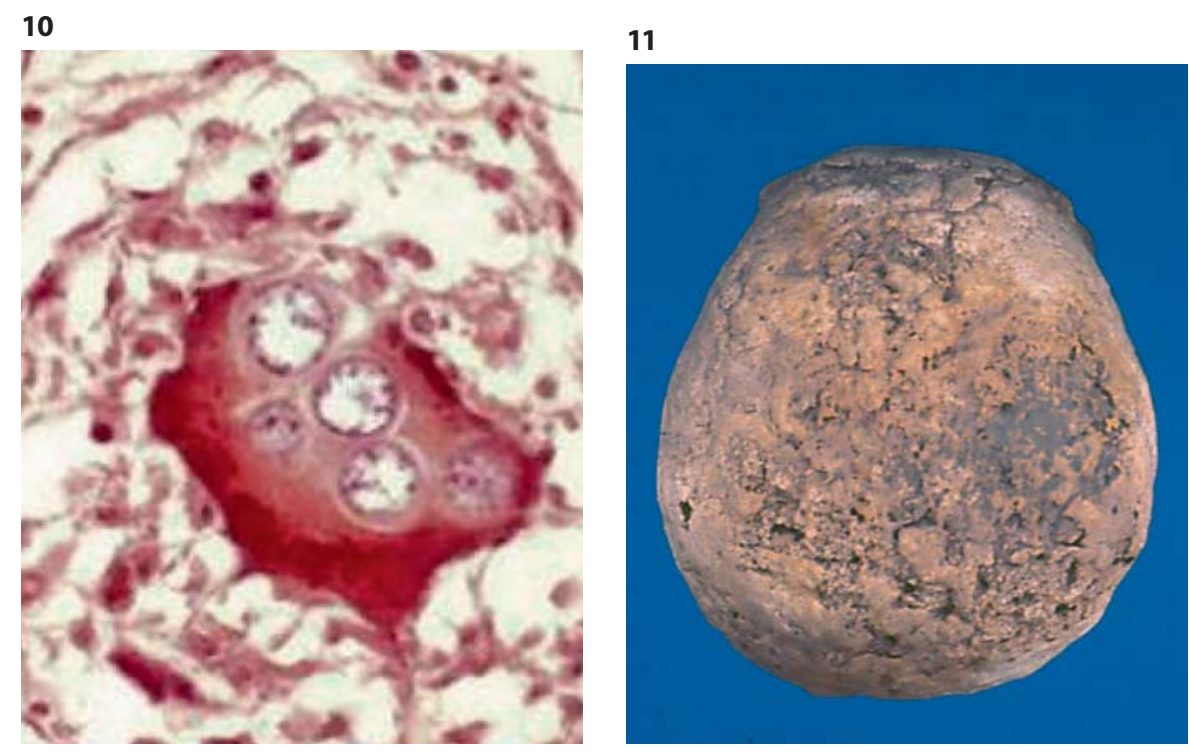

type 2 in 97\%, and cytomegalovirus in 13\%. Epstein-Barr virus was observed in $62 \%$. Cytomegalovirus was only present in the more recent mummies (500 BP) while all the other viruses were found in mummies going back at least 1,700 years. Infections due to various viruses in ancient times have also been reported by Black [12] and Li et al. [13].

\section{Syphilis}

The autopsy of several mummies demonstrated inflammatory changes, i.e. periostitis, in the tibia ('saber shins') and skull that are commonly found in syphilis, Treponema pallidum, or other treponematoses [14] (fig. 11). Other additional studies to determine serological identification were unsuccessful. In 1932, Williams [15] studied possible syphilitic lesions in pre-Columbian bones and also stressed the difficulties of the diagnosis of venereal syphilis in ancient bones. At the present time, we are not aware of definitive evidence of T. pallidum in preColumbian mummies.

\section{Parasitic Infections}

Leishmaniasis

Some investigators have maintained that leishmaniasis was introduced into the Americas in post-Columbian times, but numerous Peruvian, pre-Columbian human figures of bronze and ceramic represent lesions that are clearly consistent with this disease. Leishmaniasis is a parasitic infection caused by the bites of a sand fly, the primary vector of the infection [16]. After a bite of the vector, the parasite proliferates in the nasal area due to a lower body temperature and the lack of a cellular immune response in cartilage, which is involved early in the course of the disease as the lesion slowly advances. It begins as a painless ulcerating papule with an indurated rim. As the lesions extend, the center may attempt repairs with granulation tissue and fibrosis. Giemsa-stained organisms seen as round or oval bodies $2-3 \mu \mathrm{m}$ in length are found in phagocytic cells. They often fill the histiocytes and with the HE stain may resemble histoplasma. The ulcerative lesions involve soft tissue and cartilage, and may extend into the oral pharynx and larynx with severe facial disfigurement. Open ulcerative lesions will eventually become infected with bacteria.

An unreported case of leishmaniasis was seen in a mummy that was found on a cemetery in Ilo, Peru. The mummy was X-rayed and autopsied. The X-ray showed that the child was a 5- to 6-year-old female dating to a cultural group from 700-800 AD. The age and sex were determined by examination of the teeth and skull. The $\mathrm{X}$-ray revealed that the child had a severe facial defect, which consisted of erosion and lesions of the nose, lips, mandible, cheeks, and gums (fig. 12). In Peru, the lesions associated with leishmaniasis are referred to as 'uta.' There were also six Harris lines detected in the child's tibia, showing signs of interrupted growth, most likely having occurred in the last years of her life. Most of her organs were missing due to autolysis, but part of her lung was recovered. Upon the biopsy of the lung, there were signs of aspirations and blood clots, which likely occurred shortly before her death. 


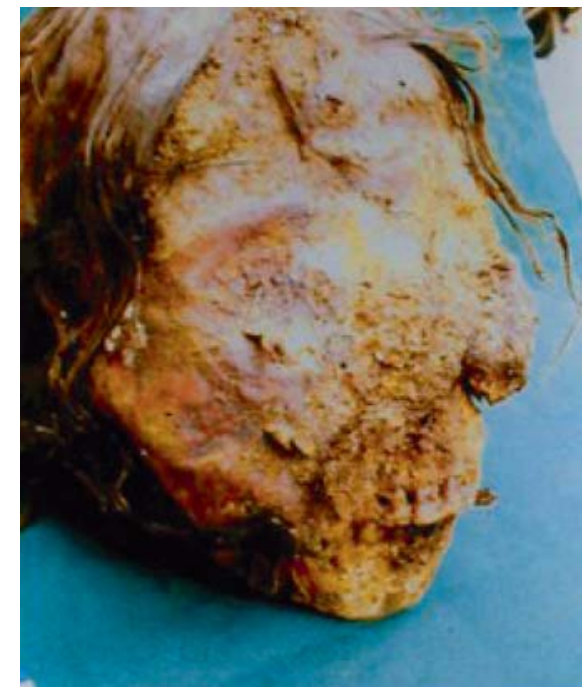

Fig. 12. Extensive lesions mainly on the right side of the face.

It is postulated that children are more likely to contract a disease such as leishmaniasis due to their weaker immune system. This makes children more susceptible to severe disfigurement and lesions. Mucocutaneous disease is typically caused by Leishmania braziliensis braziliensis [17] and is more common when skin lesions were either large or multiple. L. braziliensis peruviana typically presents itself as a primary lesion with no metastasis. This particular child did not have multiple lesions. However, the lesion on her face was large, severe and erosive. Given its size and severity and the fact that there was only a singular lesion, it is likely that the child had a L. braziliensis complex. Given the period from which the mummy dates and the culture with which it is associated, it is clear that this disease pre-dates outside contact and has been in the region for over 2,000 years. Giemsa stains showed numerous Leishmania, many with a visible membrane, nucleus, and rod-like parabasal body.

\section{Giardia lamblia and Cryptosporidium parvum}

One of the advantages of performing an autopsy on a mummy is the opportunity to open the intestines to collect fecal material. These feces can be processed in the same manner that samples from contemporary people are examined nowadays to determine the presence or absence of intestinal parasites. Finding well-formed feces in the intestines of the mummy indicates that the person was not suffering from diarrheal sickness at the time of death. However, since there were parasites present, the mummy was probably a carrier. Parasites such as Cryptosporidium and Giardia species were found in feces from the intestines of many mummies. A fluorescent antibody kit was used for the identification of these parasites.

Van Leeuwenhoek first discovered G. lamblia in his own feces in the 17th century. This parasite was also a repeated cause of diarrhea in troops during the First World War. For some time, this parasitic infection was ignored until there was a renewed interest in it after a skiers' outbreak in Aspen (Colo., USA) in 1965-1966 [18] and an epidemic in Leningrad in the 1970s [19]. Giardia is typically contracted from eating or drinking contaminated food or water.

C. parvum was a well-known cause of diarrhea in animals as early as 1907. The first case found in a human was in 1976 after the person had had contact with infected farm animals. Between 1976 and 1982, the cases in the United States were limited to immunosuppressed individuals, but in April 1992 in Wisconsin, an epidemic took place involving more than 400,000 cases, including immunocompetent hosts [20]. This epidemic was attributed to contaminated water at a chlorine treatment plant, for this parasite can survive in chlorinated and even salt water.

In our study, a total of 39 samples were analyzed for parasites [21]. Nineteen tested negative and 20 tested positive for at least one or more parasites: 7 positive samples had only 1 parasite detected, 9 positive samples had 2 parasites, 3 positive samples had 3 parasites, and 1 positive sample had 4 different parasites present. A variety of different techniques was used to identify the parasites, such as fluorescent antibody and enzyme immunoassay kits.

In summary, there were 5 different parasites identified. Seven samples tested positive for G. lamblia, 15 for C. parvum, 16 for Isospora belli, 4 for Cyclospora cayetanensis, and only 1 for Sarcocystis hominis.

\section{Malaria}

Malaria is probably one of the most ancient of human diseases [22]. It is currently increasing in prevalence, with half a billion cases in more than 100 countries worldwide. Studies by Sulzier et al. [23] in 1975 on a group of isolated Indians in the Amazon showed a high rate of malaria (63-85\%) with an etiology of only Plasmodium malariae and $P$. vivax. No P. falciparum was found. The two species for which the study population tested positive probably evolved from a primate and cross-reacted with some monkey malaria species. Some monkey malaria can be contracted by humans. Howler monkey mummies are found in ancient human cemeteries in Peru and were 
probably adopted as pets when the mother was hunted and killed for food in local coastal valleys. As coastal valley forests were cut for agriculture and coastal monkeys were killed for food, the only surviving monkeys today are now in the Amazon jungle.

Our study [24] consisted of the examination of 155 specimens (livers and spleens) from South American mummies dating from 3,000 to $600 \mathrm{BP}$ for the determination of the existence of malaria infection. The study used antibodies for P. vivax and P. falciparum with ELISA in situ hybridization. Histological sections were cut and stained with $\mathrm{HE}$ for malaria pigment. Sixty-seven percent of the specimens were found to be positive with a $4+$ reaction to P. vivax. Malaria pigment was seen in $30 \%$ of the positive cases. No reaction was detected for $P$. falciparum. This type of malaria was probably imported to America by infected African slaves, while $P$. vivax seems to have been a resident in South America for thousands of years.

\section{Helminthic Liver Disease}

One of the most well-preserved organs in the abdominal cavity is the liver. Livers taken from autopsied mummies, dated from 3,000 to $500 \mathrm{BP}$, were histologically studied to detect parasitic infection. A total of 60 livers were examined, and 5 of them showed evidence of parasitic infection. In 2 cases, cystic lesions were compatible with Echinococcus; hooklets were clearly present.

In 2 other cases, 2 young children, calcifications in the liver were detected by X-ray, and histologic examination showed worms identified as Ascaris lumbricoides. The 5 th case showed a parasite with a spine and a cuticle, resembling Fasciola hepatica.

\section{Hookworm Disease}

We previously documented the presence of parasites in the small intestine of 1 mummy [25]. The worms were identified as Ancylostoma duodenale. The diagnosis was made by histologic examination using light and scanning microscopes. This was the first evidence of a reported case of hookworm disease in the Americas prior to the arrival of Europeans. Carbon-14 performed on this mummy dated it to around $900 \mathrm{AD}$, clearly of pre-Columbian age.

\section{Chagas Disease}

This disease is caused by a parasite named Trypanosoma cruzi and occurs mainly in Central and South America. It is transmitted by many insect species belonging to the triatomids that infect numerous animals, including cats, dogs, and rodents. The insects hide in cracks of poor housing, especially the roof. Typically at night, the vector bites sleeping inhabitants. The parasites pass through the feces and enter the host through damaged skin.

In the acute phase of Chagas disease, the death rate is very low. If a fatality does occur, it is mainly due to myocarditis or meningoencephalitis. In the chronic stage, the heart is affected. Damage to the myenteric plexus causes dilation of the colon and esophagus, producing the typical megacolon that is commonly encountered in our mummies.

Aufderheide et al. [26] studied 238 tissues from mummies from valley sites in northern Chile and southern Peru from 9,000 BP to approximately the time of the Spanish conquest. In $41 \%$ of the cases, the tissues extracted were amplified by the PCR and reacted positively with the probe. Rothhammer et al. [27] studied the gross findings of 22 well-preserved mummies and found that 9 exhibited megacolon. Many of the megacolon specimens were distended with feces.

\section{Neoplasias}

A complete review of the literature of tumors in antiquity shows that in different parts of the world, relatively few types of tumors have been recorded. It is understandable that most of the findings have been described in bones [28], mainly in the skull, because the skeletal system is more resistant to deterioration over time than the soft tissues. The literature on this subject has dealt with both primary and metastatic tumors of bone. Nowadays, it is well known that primary tumors of the breast and prostate have a high frequency of metastases to bones. Few tumors of soft tissues have been documented in antiquity.

In our extensive study [29], only two soft tissue tumors were encountered. The first tumor, a benign lipoma, was an incidental finding in a male adolescent, aged 14, of northern Chile from 1,100 to 1,200 AD. On gross examination, there was a $4 \times 4 \times 2 \mathrm{~cm}$ subcutaneous mass on the right side of the chest approximately $6 \mathrm{~cm}$ below the axilla (fig. 13). Histologic sections of the chest wall mass show a conglomeration of fat cells intermingling with fibrous septa.

The second soft tissue tumor is most consistent with a rhabdomyosarcoma. It was found in a male child, approximately $12-18$ months old, of the Cabuza culture (300-600 AD) of northern Chile. The lesion was a hard swelling on the mummy's right cheek below the eye, measuring $5.5 \times 5.5 \times 2 \mathrm{~cm}$, resulting in closure of the eye. The histology of this kind of tumor shows cells forming 


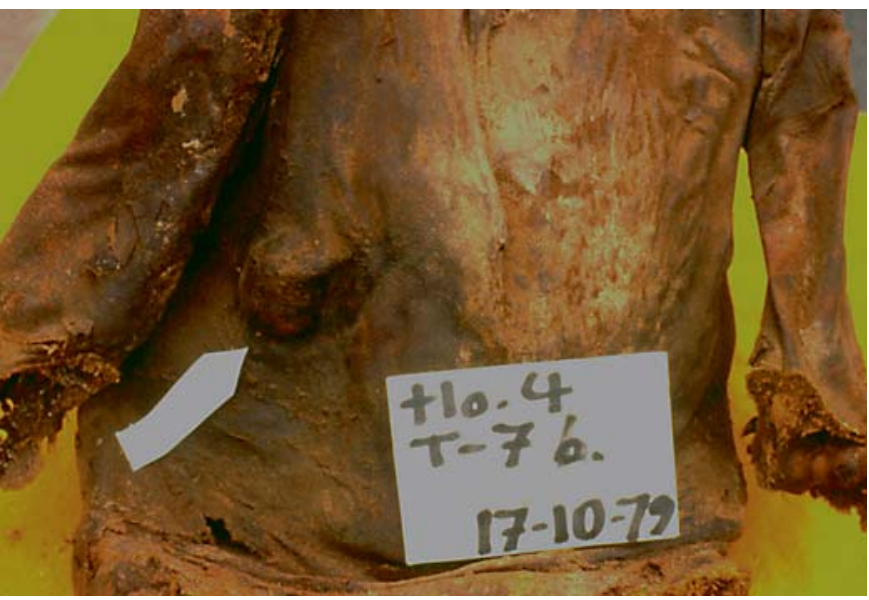

Fig. 13. Large subcutaneous tumor on the right side of the chest.

islands or broad cords, separated by fibrovascular stroma (fig. 14). Most of the cells show a shrunken cytoplasm, and in a few instances, nuclear material can be observed.

It is impossible to estimate the total number of complete skeletons and mummies that have been examined for tumors since the initial studies by Sir Ruffer in the early part of the 1900s. It has been suggested that in antiquity, people did not live long enough to develop tumors and that age is the most important factor in determining who is more likely to develop neoplastic lesions. However, in many of the pre-Columbian cultures we have studied, at least $40 \%$ of the population lived past the age of 40 years.

In the last century, numerous substances that have been associated with carcinogenesis were introduced into the daily lives of humans. It is also known now that diet has major implications for the incidence of cancer in today's world, most notably affecting carcinomas of the gastrointestinal tract. The factor likely to play a decisive role in the incidence of cancer, besides the previously mentioned factors, may be the genetic structure of the individual.

\section{Trauma}

Trauma related to warfare was evident in many of the cultures that we have studied. The most common evidence in some cultures was the presence of bodies with their heads missing, most likely taken as war trophies. Several cases of traumatic skull injury were the result of combat, both from blows to the head with clubs and from slashings with sharp weapons [30].

Paleopathology in South American Mummies

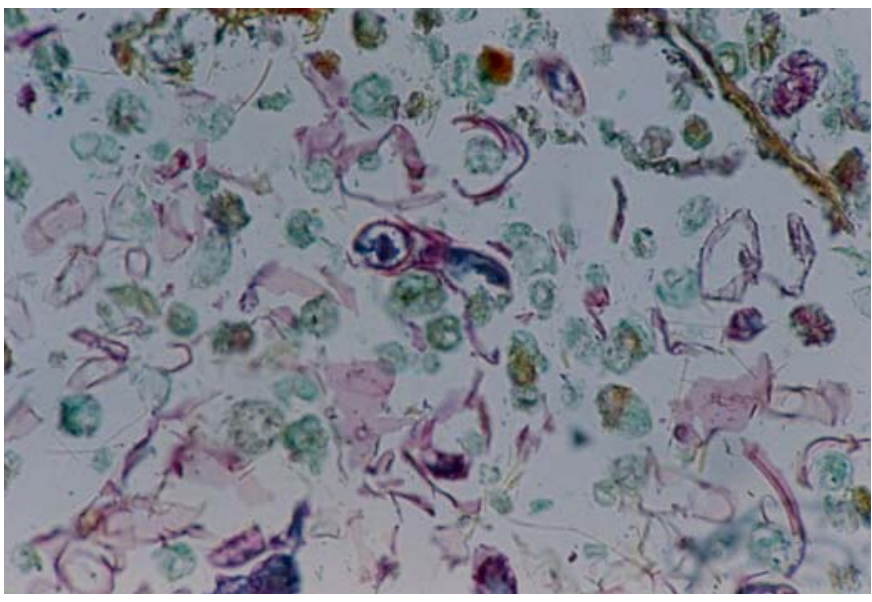

Fig. 14. Features of a malignant tumor showing pleomorphic cells.

\section{Cardiovascular System}

On gross examination of the cardiovascular system, a few mummies showed right ventricular hypertrophy. The person had died and been buried in the coastal area. However, from examination of the artifacts buried with those people, it was determined that they had normally lived in high altitudes. There is a correlation between high altitudes and right ventricular hypertrophy as a result of chronically low oxygen content. A few mummies showed mild atherosclerosis in large vessels and in coronary arteries under microscopic examination. Ruptures of blood vessels producing large amounts of hemorrhage were seen intracranially and in the abdomen, probably after warfare.

\section{Conclusion}

Paleopathology is a multidisciplinary science that includes anthropology, archaeology, pathology, history of medicine, and public health, among others. The laboratory techniques used in the approach to examining mummified human remains are similar to those currently used in forensic pathology concerned with contemporary people. One important aspect of the field of paleopathology is the comparison of current diseases to the ancient diseases in the same geographic region where the mummies were encountered in order to study the evolution of human diseases over time. 


\section{References}

1 Ruffer MA: Studies in the palaeopathology of Egypt; in Moodie RL (ed): Chicago, University of Chicago Press, 1921, pp xiii-xvi.

2 Scott G, Wyllie SJ: Bartonellosis, cat scratch disease, trench fever, human erlichiosis, whipple disease; in Cook GC, Zumla A (eds) Manson's Tropical Diseases. Amsterdam, Elsevier, 2003, pp 1091-1102.

3 Allison MJ, Pezzia A, Gerszten E, Mendoza D: A case of Carrion's disease associated with human sacrifice from the Huari culture of southern Peru. Am J Phys Anthropol 1974; 41:295-300.

4 Allison MJ, Mendoza D, Pezzia A: Documentation of a case of tuberculosis in preColumbian America. Am Rev Respir Dis 1973;107:985-991.

$\checkmark 5$ Salo WL, Aufderheide AC, Buikstra J, Holcomb TA: Identification of Mycobacterium tuberculosis DNA in a pre-Columbian Peruvian mummy. Proc Natl Acad Sci USA 1994; 91:2091-2094.

-6 Eiesenach KD, Cave MD, Bates JH, Crawford JT: Polymerase chain reaction of a repetitive DNA sequence specific for Mycobacterium tuberculosis. J Infect Dis 1990;161:977-981.

$>7$ Allison MJ, Gerszten E, Shadomy J, Munizaga J, Gonzalez M: Paracoccidioidomycosis in a northern Chilean mummy. Bull NY Acad Med 1979;55:670-683.

$\checkmark 8$ Fountain FF, Sutliff WD: Paracoccidioidomycosis in the United States. Am Rev Respir Dis 1969;99:89-93.

9 Posada A: Un nuevo caso de micosis fungoidea con Psorospermias. An Circ Med Argent 1892;15:585-597.

10 Canteros CE, Toranzo A, Suarez-Alvarez R, Davel G, Castañon-Olivares LR, Napoli J: Identidad genetica del hongo causante del primer caso de Coccidioidomycosis descripto por Alejandro Posadas en 1892. Medicina 2009;69:215-220.
11 Woodson EA: Chronic Viral Disease in PreColumbian Indians. USCAP 2001;90:21.

12 Black F: Infectious diseases in primitive societies. Science 1975;187:515-518.

13 Li HG, Fujiyoshi T, Lou H, Yahiki S, Sonoda S, Munoz I, Horai S, Tajima K: The presence of ancient T-cell lymphotrophic virus type 1 provirus DNA in an Andean mummy. Nat Med 1999;5:1428.

14 Gerszten E, Allison MJ: Paleopathology of infectious diseases in South American mummies. Pathol Int 1994;54:5440.

15 Williams HU: The origin and antiquity of syphilis; the evidence from diseased bones. A review, with some new material from America. Arch Pathol 1932;13:931.

16 Herrer A, Christensen HA: Implications of Phlebotomus sand flies as vector of bartonellosis and leishmaniasis as early as 1764 . Science 1975; 190:154-155.

17 Jones TC, Johnson WD, Barretto AC, et al: Epidemiology of American cutaneous leishmaniasis due to Leishmania braziliensis braziliensis. J Infect Dis 1987;156:73-83.

18 Moore GT, Cross WM, McGuire D, et al: Epidemic giardiasis at a ski resort. $\mathrm{N}$ Engl J Med 1969;281:402-407.

19 Brodsky RE, Spencer HC Jr, Schultz MG: Giardiasis in American travelers to the Soviet Union. J Infect Dis 1974;130:319-323.

20 MacKenzie WR, Schell WL, Blair KA, et al: Massive outbreak of waterborne Cryptosporidium infection in Milwaukee, Wisconsin: recurrence of illness and risk of secondary transmission. Clin Infect Dis 1995;21:57-62.
21 Allison MJ, Bergman T, Gerszten E: Further studies on fecal parasites in antiquity. Am J Clin Pathol 1999;112:605-609.

22 Bruce-Chwatt LJ: Paleogenesis and paleoepidemiology of primate malaria. Bull World Health Org 1965;32:363-687.

23 Sulzier AJ, Cantella R, Colichon A, Gleason NN, Walls KW: A focus of hyperendemic Plasmodium malariae-P. vivax with no P. falciparum in a primitive population in the $\mathrm{Pe}$ ruvian Amazon jungle. Bull World Health Org 1975;52:273-278

24 Allison MJ, Guillen S, Gerszten E, Caldwell $\mathrm{N}$ : Plasmodium vivax malaria: a native preColumbian disease. Modern Pathol 2009;22: 293A.

25 Allison MJ, Pezzia A, Hasegawa I, Gerszten E: A case of hookworm infestation in a preColumbian American. Am J Phys Anthropol 1974;41:103-106

26 Aufderheide AC, Wilmar S, Madden M, Streitz J, Buikstra J, Guhl F, Arriaza B, Reiner C, Wittmers LE, Fornaciari G, Allison MJ: A 9,000-year record of Chagas' disease. Proc Natl Acad Sci USA 2004;101:20342039.

27 Rothhammer F, Allison MJ, Nuñez L, Standen V, Arriaza B: Chagas' disease in pre-Columbian South America. Am J Phys Anthropol 1985;68:495-498.

28 Allison MJ, Gerszten E, Munizaga J, Santoro C: Metastatic tumor of bone in a Tiahuanaco female. Bull NY Acad Med 1980;56:581-587.

29 Gerszten E, Allison MJ: Human soft tissue tumors in paleopathology; in Ortner DJ, Aufderheide AC (eds): Human Paleopathology: Current Synthesis and Future Options. Washington, Smithsonian Institution Press 1991, pp 257-260.

-30 Gerszten PC, Gerszten E, Allison MJ: Diseases of the skull in pre-Columbian South American mummies. Neurosurgery 1998; 42:1-7. 